\title{
Os símbolos da República nas páginas do humor: Política e imprensa ilustrada no Rio de Janeiro dos anos 1870
}

Aristeu Machado Lopes*

Resumo: Os periódicos ilustrados do Rio de Janeiro alcançaram notoriedade a partir da segunda metade do século XIX. Parte do sucesso ocorreu devido às suas características peculiares, ou seja, além de noticiar, seu objetivo também era ocasionar o riso do leitor com desenhos humorísticos. Por outro lado, a atuação de artistas estrangeiros contribuiu para o desenvolvimento e a consolidação desse tipo de imprensa no Brasil Imperial. No conjunto das temáticas abordadas em suas páginas, destacou-se a atenção dada à política do tempo. Entre essas ilustrações, surgiam os símbolos republicanos, para tratar das ideias republicanas propagadas pelos seus defensores. Averiguar a relação entre esses símbolos, a discussão política republicana e o humor dos periódicos é o objetivo deste artigo. Nesse momento, a análise trata de um dos símbolos republicanos: a alegoria feminina empregada pelos caricaturistas na composição das suas ilustrações.

Palavras-chave: Imprensa Ilustrada. Simbologia republicana. Rio de Janeiro. Século XIX.

\section{Considerações Iniciais}

A imprensa ilustrada começou a circular no Brasil a partir dos anos 1830. Contudo, foi somente nas últimas décadas do século XIX que surgiram jornais de ilustrações com uma longevidade significativa. O Rio de Janeiro, centro político do Império do Brasil,

\footnotetext{
* Mestre e doutor em História pela Universidade Federal do Rio Grande do Sul. Professor do Departamento e do Programa de Pós-Graduação em História da Universidade Federal de Pelotas. E-mail: aristeuufpel@yahoo.com.br
} 
Os símbolos da República nas páginas do humor: Política e imprensa...

concentrou a maioria desses periódicos, os quais eram confeccionados baseados no sucesso alcançado por publicações congêneres na Europa, em cidades como Londres e Paris (FONSECA, 1999). No conjunto dos periódicos fluminenses, se destacaram a Semana Illustrada (1860-1876), O Mosquito (1869-1877), A Vida Fluminense (1868-1875), Revista Ilustrada (1876-1898) e O Mequetrefe (1875-1893). Esse tipo de imprensa também se desenvolveu em outros centros urbanos brasileiros, principalmente a partir do final do século XIX, quando ocorreu o surgimento de vários periódicos e revistas de humor em cidades como São Paulo e Porto Alegre (SALIBA, 2002, p. 38).

Os periódicos do Rio de Janeiro podem ser considerados precursores deste tipo de imprensa irreverente, que aliava humor, notícia e crítica da sociedade. Dessa forma, uma das temáticas mais exploradas pelos periódicos foi a política do tempo, aproveitada pelos artistas na produção de seus desenhos humorísticos. Vale ressaltar que a proposta principal dos periódicos era uma abordagem diferente daquela formal, séria, dos jornais diários, ou seja, as ilustrações apresentavam uma visão descontraída das notícias políticas e cotidianas. Nas páginas dos periódicos surgiram as disputas entre liberais e conservadores, a formação dos gabinetes imperais e um peculiar Imperador Dom Pedro II descrito como "Pedro Banana" ou "Pedro caju" (SCHWARCZ, 1998. p. 420). Ao lado dessas temáticas, uma questão que ainda era pequena principiava a surgir nas discussões políticas e começava a ser noticiada nos jornais ilustrados: a República e o surgimento de uma campanha favorável a essa forma de governo no Brasil.

O crescimento da imprensa ilustrada coincidiu com o aumento da campanha republicana impulsionada pela fundação do Partido Republicano, em 1870, que logo inaugurou um órgão oficial para fomentar a propaganda (BOEHRER, 2000, p. 41-47). Averiguar como os símbolos da República foram aproveitados pelos caricaturistas para abordar em suas ilustrações o debate político e, em especial, o ideário republicano dos anos 1870 é o principal objetivo deste artigo. Entre os periódicos do Rio de Janeiro citados acima, neste trabalho serão analisadas imagens veiculadas na Semana Illustrada, A Vida Fluminense e em O Mosquito.

Nesses periódicos a questão republicana foi tratada sempre a partir dos símbolos do conjunto alegórico republicano. Assim, nas 
ilustrações analisadas surgiram algumas versões da Alegoria Feminina da República, adaptada do ideário revolucionário e republicano francês difundido, sobretudo, após a Revolução Francesa de 1789 e a Primeira República Francesa, em 1792 ${ }^{1}$. Nas demais, outros elementos como o barrete frígio e as fasces identificam a temática republicana abordada nas ilustrações. O emprego dos símbolos republicanos nos periódicos remetia ao leitor a ideia abstrata da República e nesse quesito não se distanciavam do caso francês. Maurice Agulhon (1979, p. 08) salienta, ao tratar do emprego das alegorias, dos símbolos e dos emblemas na França, que eles constituem imagens que correspondem a ideias abstratas como Liberdade, República, Revolução, França. No Brasil, os mesmos símbolos foram adaptados pelos caricaturistas para falar do partido, da campanha, do órgão oficial e dos principais republicanos.

Este artigo compartilha com a opinião da historiadora Tania de Luca, que enfatiza a importância de uma escrita da história por meio da imprensa. Em outras palavras, os periódicos

[...] oferecem oportunidades privilegiadas para explicitar e dotar de densidade os embates em torno de projetos políticos e questões artístico-literárias que, longe de esgotaremse em si mesmas, dialogam intensamente com os dilemas do tempo (LUCA, 2011, p. 2-3).

A imprensa, antes considerada uma fonte não confiável pelos historiadores, pois “"...] os jornais pareciam pouco adequados para a recuperação do passado, uma vez que 'essas enciclopédias do cotidiano’ continham registros fragmentários do presente” (LUCA, 2006, p. 112), se tornou, nos últimos anos, importante na produção historiográfica.

Assim sendo, os periódicos analisados neste texto constituem uma fonte de pesquisa que permite compreender um momento da história do Brasil Imperial demarcado pelo surgimento de grupos políticos, como, entre outros, os liberais radicais e os republicanos. Compreender o porquê da atenção dada pelos artistas a esse debate político é a questão primordial deste artigo. Em outras palavras, a campanha republicana constituía um risco ao 
Os símbolos da República nas páginas do humor: Política e imprensa...

Império do Brasil? Ao longo do desenvolvimento do texto, pretende-se responder a indagação a partir da análise das ilustrações, as quais demonstram estarem tomadas de posição diferenciadas. Se, por um lado, as imagens produzidas pela Semana Illustrada denotam uma depreciação do ideário republicano, aquelas veiculadas nos demais periódicos adotaram um tom que, em determinadas ilustrações, pode ser considerado simpático.

\section{Os Símbolos da República na Imprensa Ilustrada}

A Semana Illustrada foi o primeiro periódico com ilustrações que alcançou sucesso. O jornal foi fundado pelo prussiano Henrique Fleiuss em 1860 e conseguiu manter a sua circulação regularmente até 1876. É considerado bem-sucedido, uma vez que todas as experiências anteriores não alcançaram a longevidade que a Semana atingiu. Contudo, havia uma difusão da técnica litográfica marcada por um "momento de franca produção editorial de estampas e jornais, embora efêmeros e, por vezes, acríticos” (SALGUEIRO, 2003, p. 82).

Henrique Fleiuss foi o seu principal, e por quase todos os 16 anos, o único artista envolvido na confecção do periódico. Ele foi constantemente acusado por outros jornais do Rio de Janeiro de ser simpático ao Imperador e à política monárquica. No entanto, como destaca Lúcia Guimarães (2006, p. 92) “[...] o lápis ágil e de ponta afiada de Henrique Fleiuss estava sempre pronto para satirizar as práticas pouco recomendadas dos políticos e das elites dirigentes". Como será tratado adiante, o lápis do artista, no que se refere à questão republicana, também foi ágil e afiado, mas para criticar a campanha.

Já A Vida Fluminense surgiu em 1868 e permaneceu até 1875; o jornal se intitulava "folha joco-séria ilustrada" e publicava "revistas, caricaturas, retratos, modas, músicas, etc, etc" (A Vida Fluminense, $01 / 01 / 1868)^{2}$. No que se refere à questão política, um dos temas amplamente divulgados foi a Guerra do Paraguai (1864-1870). Os leitores eram informados não só dos acontecimentos e dos avanços dos aliados nas batalhas, como também a eles eram oferecidos desenhos dos mapas das operações militares, de membros de grande destaque do exército, e caricaturas satirizando os inimigos (TORAL, 
2001). Participaram da parte ilustrada de $A$ Vida Fluminense Angelo Agostini, Antonio Alves do Vale de Sousa Pinto, Candido Aragonês de Faria e Luigi Borgomainerio.

O Mosquito (1869-1877) foi fundado por Candido Aragonês de Faria e contou ainda com outros caricaturistas em diversos momentos: Pinheiro Guimarães, Flumen Junius, Antonio Augusto do Vale, Angelo Agostini e Rafael Bordallo Pinheiro. O Mosquito apresentava-se como "jornal caricato e crítico" e, conforme sua apresentação, tinha por objetivo

Beliscar, sutilmente, a humanidade; enterrar mesmo o fer-
rão em certos preconceitos e alusões da nossa sociedade
sem deixar calombo ou comichão, é essa a missão deste
pequeno filho do Adão mosquital da criação (O Mosquito,
19/09/1869).

Candido de Faria não permaneceu por todo o período no jornal. Em alguns momentos, atuou em outros periódicos para depois retornar para O Mosquito. A mudança de status de um caricaturista que passava de colaborador de um periódico a proprietário de um novo jornal, possivelmente era motivada não só pela obtenção de uma renda financeira melhor, como também pelo reconhecimento de seu talento como artista ${ }^{3}$. Candido de Faria assim procedeu, embora as tentativas tenham sido frustradas. Seu reconhecimento foi alcançado depois que deixou a Corte em 1878, na expectativa de alcançar sucesso e retorno financeiro num outro centro urbano que não contasse com um número significativo de desenhistas. Primeiro, se estabeleceu em Porto Alegre e lançou O Fígaro, mantido por cerca de oito meses. Depois mudou-se para Buenos Aires colaborando no El Mosquito e a partir de 1880 no periódico La Cotorra (FERREIRA, 1964, p. 62-63). Mais tarde, foi para Paris e estabeleceu um ateliê, alcançando sucesso com ilustrações de livros, partituras e cartazes publicitários.

Importante colaborador foi Angelo Agostini, um imigrante italiano que iniciou sua profissão de caricaturista em São Paulo, nos periódicos Diabo Coxo (1864-1865) e Cabrião (1865-1867). Ao se estabelecer na Corte, trabalhou em alguns periódicos antes de 
Os símbolos da República nas páginas do humor: Política e imprensa...

ingressar em O Mosquito. Ao se retirar deste periódico, lançou, em 1876, a Revista Illustrada, da qual se afastaria somente em 1888 (BALABAN, 2009).

Ao contrário da Semana Illustrada, que aparentemente nutria uma tendência monarquista, A Vida Fluminense não apresentou sim(0) patias ao Império, e também não se caracterizou como um periódico filiado a partidos políticos; a política da época era tomada de uma forma genérica, e, quase sempre, em tom de sátira. Já O Mosquito afirmava que iria "ocupar-se de política", mas de uma política "sem bandeira, sem compromissos, sem compadrescos, sem rolha" (O Mosquito, 02/09/1871).

Se os políticos do tempo e até mesmo o Imperador eram constantemente satirizados, os republicanos não escapavam do lápis afiado dos caricaturistas; no mesmo ritmo em que os republicanos propagavam sua campanha, eles eram comentados nos periódicos. O ideário republicano e seus símbolos apareciam com maior abrangência nas páginas de $O$ Mosquito do que em $A$ Vida Fluminense. $\mathrm{O}$ posicionamento dos dois jornais não pode ser classificado ou reduzido somente a "favorável" ou "contrário" a República. Na maioria da vezes, os símbolos foram usados mais para noticiar ou comentar - quase sempre com humor - do que para criticar as atitudes republicanas. Já na Semana Illustrada, os símbolos apareciam com certa regularidade, e num tom depreciativo.

\section{Quando vira a Ampulheta...}

Em O Mosquito, uma das primeiras alusões tratava das aspirações republicanas na conquista por novos simpatizantes. No desenho, uma ampulheta, contendo de um lado a República e do outro a Monarquia, demonstrava uma situação que ocorria na política imperial, e da qual os republicanos não seriam exceção: a troca de partidos (Figura 1). 


\section{Figura 1: Política Nacional}

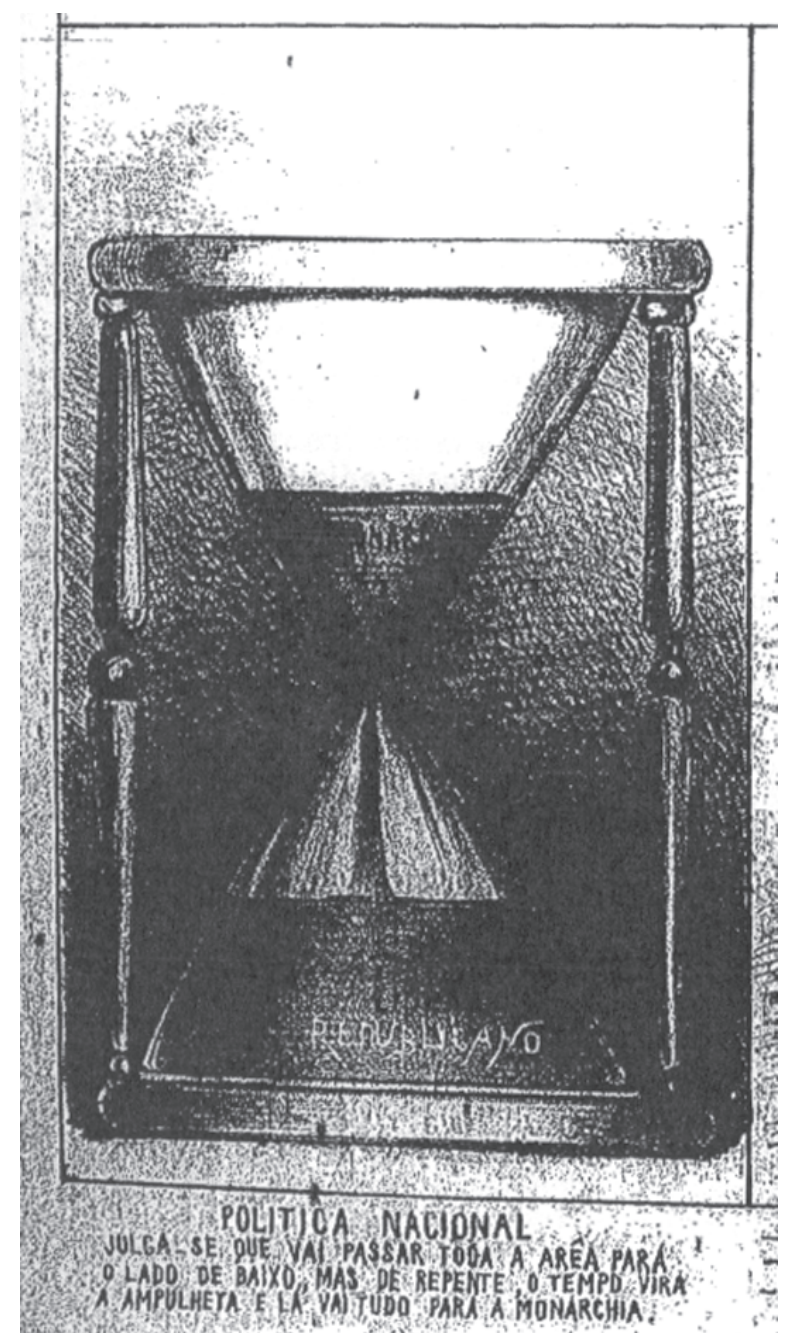

Fonte: O Mosquito, Rio de Janeiro, n. 69, p. 4, 06 jan. 1871. Acervo: AEL-UNICAMP

A legenda esclarece: "Política Nacional. Julga-se que vai passar toda a areia para o lado de baixo, mas de repente o tempo vira a ampulheta e lá vai tudo para a Monarquia" (O Mosquito, 06/01/1871).

Alguns políticos mudavam constantemente de partido saindo, na maioria das vezes, devido a desentendimentos com companheiros de sigla. Essa pequena ilustração tratava dessa prática, que se tornou corriqueira na política imperial. O próprio Partido Republicano contou com a participação de ex-membros de partidos 
Os símbolos da República nas páginas do humor: Política e imprensa...

já estabelecidos, destacando-se aqueles oriundos das frentes liberais. Contudo, quando o Partido Liberal retornava ao poder à frente da Presidência do Conselho de Ministros, os membros republicanos tornavam-se novamente liberais (BOEHRER, 2000, p. 38). Houve alguns membros que, apesar de terem sido simpáticos à causa repu(0) blicana e terem participado desde 1870 do partido, mantendo-se fiéis aos seus ideais (como por exemplo Joaquim Saldanha Marinho), continuaram concorrendo a cargos políticos pelo Partido Liberal (HOLANDA, 2005, p. 299-300).

Estabeleceu-se com essa circunstância uma linha difícil de ser traçada, separando liberais e republicanos. Tal dificuldade foi também explorada nos periódicos ilustrados que associavam republicanos e liberais. Dessa forma, é possível considerar que as ilustrações dos periódicos possibilitam uma análise nova no que se refere ao debate político desenvolvido no Brasil do século XIX. Se, por um lado, o humor e a comicidade eram um dos fundamentos dos periódicos, por outro, assuntos importantes do cenário político também mereciam a atenção dos artistas. Com o auxílio das imagens sobre a campanha republicana, como aquelas que apresentam as alegorias femininas da República, é evidenciado que os periódicos ilustrados estavam atualizados sobre as discussões do seu tempo, como demonstra a ilustração sobre a ampulheta analisada acima, e as demais que serão tratadas no andamento do texto.

\section{As grandes cabeças do século}

Numa das ilustrações de $A$ Vida Fluminense, a posição ambígua entre os membros dos partidos era exposta com a caricaturização de um deles literalmente dividido, e indeciso, entre os dois partidos (Figura 2). 


\section{Figura 2: As grandes cabeças do século}

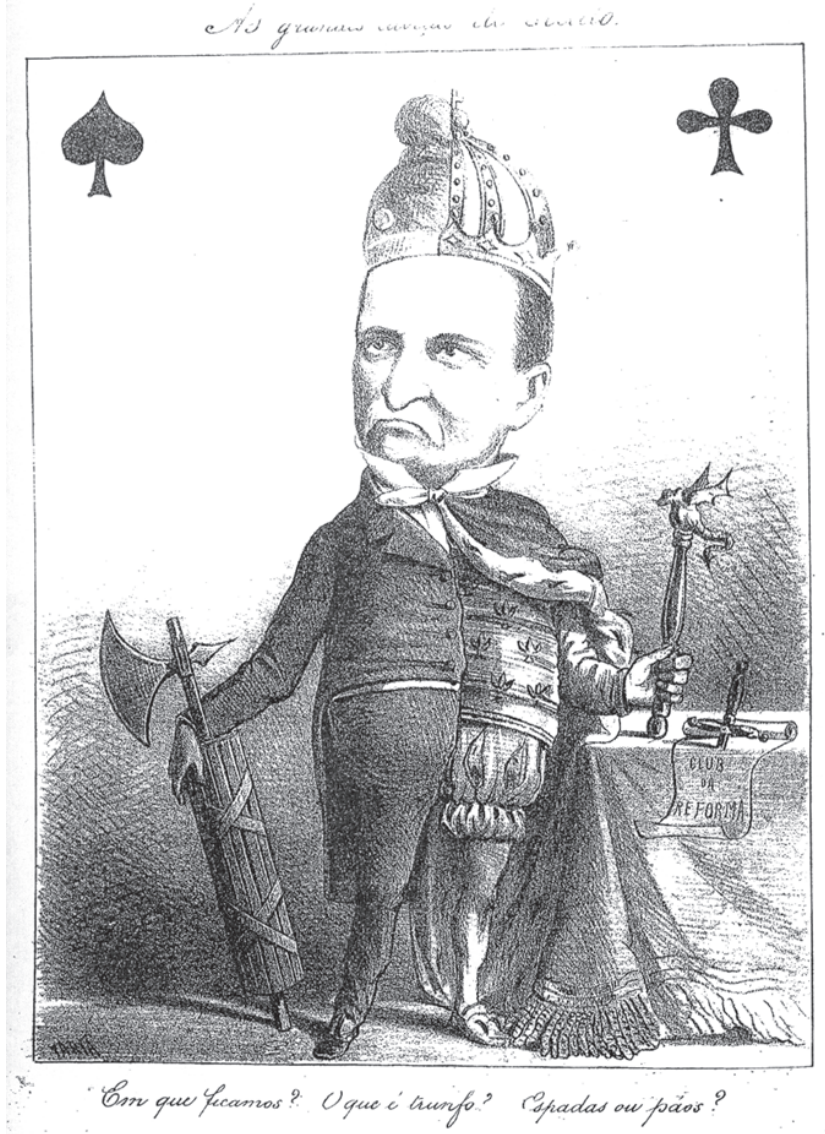

Fonte: A Vida Fluminense, Rio de Janeiro, n. 249, p. 1154, 05 out. 1872. Acervo: AEL-UNICAMP

A imagem publicada em 05 de outubro de 1872, intitulada "As grandes cabeças do século", apresentava um homem trajando vestes peculiares, que denotavam a divisão de sua simpatia e uma dúvida, ou seja, se liberal ou republicano. Em 1872, ano da publicação da ilustração, ocorreram eleições para a Câmara de Deputados e, provavelmente, tal imagem se referia a esse episódio. Apesar de não ser possível identificar quem é o caricaturado, a imagem remete a indecisão que não era apenas de um homem, mas de vários possíveis candidatos, divididos entre a defesa da causa dos liberais radicais ou dos republicanos. Essa questão estava relacionada ao fato de que tanto o Partido Republicano como a atuação dos liberais radicais ainda era recente no debate político que ocorria em 1872. Ainda no pleito ocorrido naquele ano, os candidatos liberais, como 
Os símbolos da República nas páginas do humor: Política e imprensa...

coloca José Murilo de Carvalho, se abstiveram de concorrer "em protesto pela dissolução da Câmara anterior" (CARVALHO, 2007, p.407).

Outra questão que pode ser explorada a partir desta imagem refere-se ao objetivo do periódico, conforme a sua apresentação. $A$ Vida Fluminense afirmava ser uma "folha joco-séria ilustrada", como já visto acima; o periódico, portanto, abordaria os assuntos de maneira jocosa e, ao mesmo tempo, séria. A ilustração ora analisada permite exemplificar essa escolha. É possível visualizar o tom jocoso com a apresentação de um homem trajando duas vestes diferentes, e com uma cabeça avantajada em relação ao corpo. Por outro lado, trata-se de um assunto sério: o período eleitoral e o debate gerado pelos novos grupos políticos que começavam a figurar na arena política do Império.

O lado esquerdo do caricaturado foi concebido com casaco e calças de um homem comum do século XIX; na sua mão está um fasces, ou feixe de varas, outro elemento da simbologia republicana adotado da Roma Republicana Antiga. Esse símbolo era empregado para representar a união (HUNT, 2007, p. 85); trata-se de um feixe de varas reunidas numa forma cilíndrica, e ligadas a um machado $^{4}$. Já o seu lado direito foi vestido com roupas que se assemelham àquelas usadas por reis; nota-se que a partir do seu pescoço se desdobra um manto, e sua mão traz uma espada coberta por sua capa, na qual há um dragão (símbolo imperial) na ponta.

O adereço da cabeça do homem também foi dividido. O lado direito com uma coroa, e o lado esquerdo com um barrete frígio. Este era outro símbolo republicano importante usado pelos caricaturistas para identificar os republicanos e os liberais radicais. O barrete frígio foi, da mesma forma que a Alegoria Feminina da República, difundido a partir da Revolução Francesa, em 1789. Usado na Roma Antiga por ex-escravos para identificar a sua nova condição de homens livres, na França se tornou um atributo para caracterizar os sans-culottes (CARVALHO, 1990, p. 75). Conforme Michel Vovelle (1997, p. 177), foi nos primeiros dias da Revolução que a figura indistinta do sans-culotte surgiu no meio da multidão, reconhecido por sua roupa e pelo barrete.

O desenho foi enquadrado para passar a ideia de que se tratava de uma carta de baralho, o que pode ser visualizado com os dois naipes colocados nos cantos superiores, sendo que o símbolo 
da esquerda se refere à carta de paus, e o símbolo da direita à carta de espadas. A proposta foi reforçada com as perguntas que servem de legenda à imagem: "Em que ficamos? O que é triunfo? Espadas ou paus?". O enquadramento, como uma carta, e a última pergunta fazem referência ao jogo político daquele momento. Assim, não somente a forma como o homem é apresentado indica indecisão, como também a pergunta na legenda possibilita torná-la mais evidente: "espadas ou paus?", significa, respectivamente, "liberais radicais ou republicanos?”. Tal escolha não parece ficar restrita somente ao candidato apresentado na ilustração. A primeira pergunta é mais específica, e é possível considerar que ela é feita, igualmente, aos leitores. "Em que ficamos?" pode ser lida como "em quem votamos?", ou seja, as perguntas remetem, da mesma maneira que a ilustração da ampulheta, à indecisão em relação aos posicionamentos e às escolhas partidárias. A dúvida parece se dirigir não somente aos futuros candidatos que disputariam os cargos políticos, mas também aos eleitores.

Retomando o desenho, é possível considerar que o caricaturado é um simpatizante tanto dos liberais radicais como dos republicanos. Pelo lado esquerdo ele é todo caracterizado como um republicano, com o feixe de armas e o barrete frígio. E o seu lado direito é compostos por símbolos monárquicos, o manto e a coroa. Os liberais foram associados com elementos da Monarquia, porque ao lado dos conservadores constituíram os dois partidos monárquicos estabelecidos, enquanto os republicanos eram os seus opositores. Os partidos políticos receberam a denominação de "partido de esquerda" ou de "partido de direita" após a Revolução Francesa. Os termos foram definidos à época da Assembléia Legislativa Constituinte, chamada de Convenção Nacional, instituída em 1792. Do lado direito ficavam concentrados os deputados oriundos da grande burguesia, os Girondinos, e ao lado esquerdo agrupavam-se os deputados da pequena burguesia, e os Jacobinos. Para Lynn Hunt (2007, p. 161), direita e esquerda constituem "clássicas categorias políticas de divisão". As posições em que os partidos abordados na ilustração de $A$ Vida Fluminense foram alocados na carta do baralho não eram ocasionais. Elas se referiam a duas categorias políticas: os liberais como integrantes de um partido de direita e os republicanos representando o partido da esquerda. 
Os símbolos da República nas páginas do humor: Política e imprensa...

Contudo, como será tratado nos parágrafos seguintes, a parte liberal do homem da imagem denota que ele é simpatizante de uma ala do partido, aquela considerada radical.

Um outro item colocado na ilustração é a mesa que está no lado monárquico. Sobre ela, uma pequena espada está cravada, segurando um papel com a inscrição "Club da Reforma", numa alusão aos liberais e ao órgão do seu partido, A Reforma. A folha liberal apareceu nos periódicos ilustrados quase sempre associada com outro jornal, $A$ República, lançado pelos republicanos em 1870 para propagar suas ideias.

O jornal $A$ Reforma foi fundado em maio 1869 por membros do Centro Liberal, formado por liberais que pretendiam revitalizar o partido. Contudo, a renovação pretendida sugeria mudanças significativas, tanto no partido como na própria administração do país. No mesmo mês de sua fundação, o Centro lançou um manifesto e um novo programa partidário. O texto encerrava com a seguinte premissa: "Ou a reforma, ou a revolução; a reforma para conjurar a revolução" (Apud CARVALHO, 2007, p. 24). O jornal A Reforma, e os liberais de uma forma abrangente, apareciam nas páginas dos periódicos, e não somente na Semana, com barrete frígio. O tom reformador adotado pelos liberais radicais foi, provavelmente, o que possibilitou esse emprego e a associação com os republicanos. Essa assimilação, entretanto, não era equivocada, uma vez que nos anos 1870 começava a se organizar no Rio de Janeiro uma oposição melhor organizada e múltipla contra a Monarquia. Quando da formação dos grupos opositores, nem sempre era possível distinguir quais as ideologias que eram defendidas por cada um deles (ALONSO, 2002).

A origem da simpatia dos liberais pela República pode ser encontrada com a crise, e consequente queda, do Gabinete Zacarias, em 1868. O resultado foi uma cisão entre os liberais, que se dividiram em duas alas: uma formada por moderados e a outra por radicais. "Os elementos da ala radical, que então se forma, evoluíram na sua maioria para a ideia republicana” (COSTA, 2007, p. 481).

Ainda, é possível assegurar que a difusão do manifesto dos liberais foi um dos motivos que levaram os periódicos ilustrados à associação entre liberais radicais e republicanos, apresentando-os aos seus leitores como defensores de ideias semelhantes, embora 
os primeiros ainda fossem vinculados a um partido monárquico, e os outros a um partido novo, recém fundado na Corte. O jornal dos republicanos foi o primeiro órgão de imprensa do Império a defender abertamente os ideais difundidos por seus simpatizantes, a partir dos anos 1870. Entre seus colaboradores, estavam Quintino Bocaiúva, Aristides Lobo, Salvador de Mendonça, Lafayette Rodrigues Pereira e Francisco Rangel Pestana. As ilustrações que serão analisadas a seguir coincidem com o momento de expansão da folha republicana, que se tornava diária, com formato maior e uma tiragem de 2000 exemplares (BOEHRER, 2000, p. 48).

\section{Duas comadres}

Na Semana Illustrada, dois jornais - o dos liberais e o dos republicanos - surgiram em suas páginas, revelando um posicionamento mais crítico do que aquele averiguado em seus congêneres. $\mathrm{Na}$ ilustração seguinte, o periódico apresentava duas figuras femininas simbolizando os jornais $A$ República e $A$ Reforma (Figura 3).

\section{Figura 3: Duas comadres}

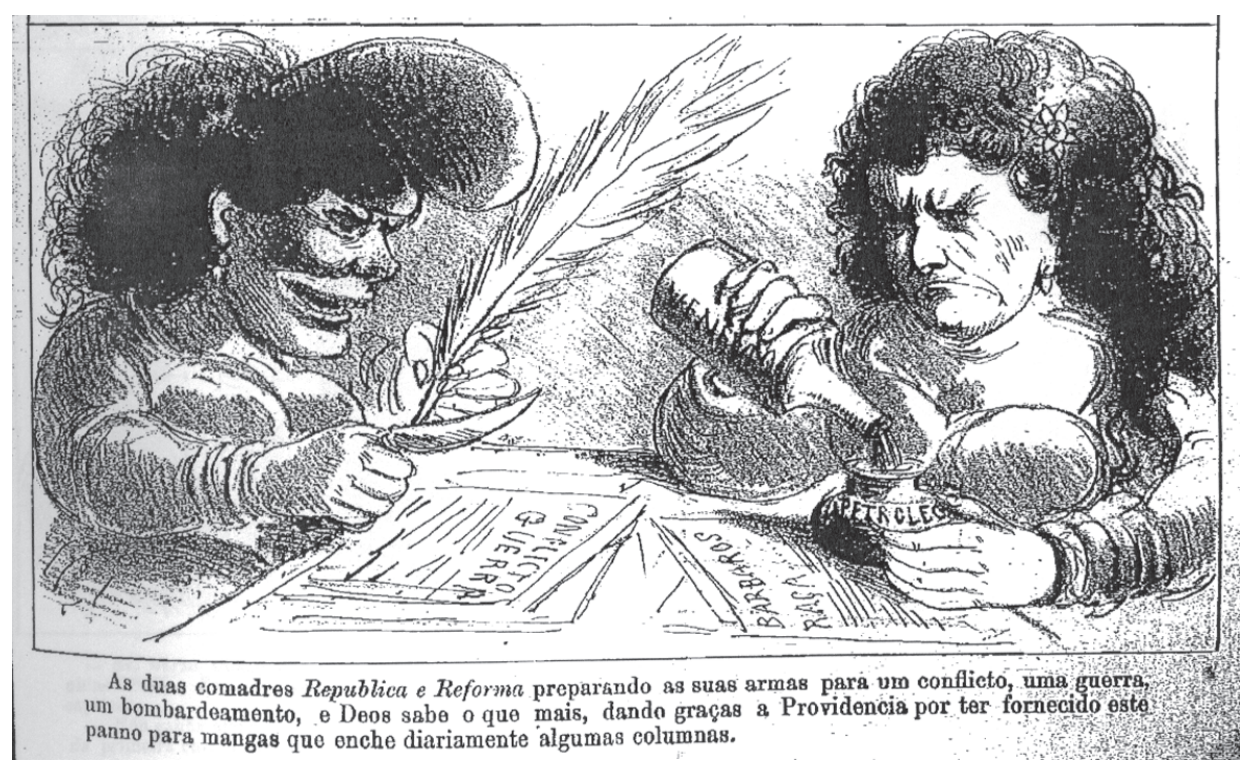

Fonte: O Mosquito, Rio de Janeiro, n.136, capa, 20 abr. 1872.

Acervo: AEL-UNICAMP

Anos 90, Porto Alegre, v. 19, n. 36, p. 221-249, dez. 2012 
Os símbolos da República nas páginas do humor: Política e imprensa...

$\mathrm{Na}$ ilustração, $A$ República e $A$ Reforma foram transformadas em duas comadres. Ambas possuem traços semelhantes e acentuados: corpo avantajado, e seios e mãos agigantadas. A República ostenta seu barrete frígio e possui uma expressão mais caricata, e seu sorriso largo entrega seu caráter zombeteiro (parece que está gargalhando), pois ela se diverte com o conteúdo que será publicado na folha. Já a "comadre" A Reforma tem uma expressão mais séria. Ela está concentrada no desempenho de seu trabalho de misturar "veneno" com "petróleo". Petróleo nesse sentido pode ser entendido como algo falso ou ainda fantasioso, o que caracterizaria, na visão do caricaturista, as notícias veiculadas pelo jornal.

A palavra "petróleo" aplicada na identificação de algo falso, como por exemplo, nas notícias veiculadas no jornal dos liberais, na ilustração da Semana, pode ter surgido no século XIX devido às várias tentativas frustradas de encontrar o produto no território brasileiro, expectativa que deve ter gerado várias notícias falsas. As primeiras tentativas ocorreram em 1858, na Província da Bahia. Contudo, foi somente no final dos anos 1930 que a produção petrolífera iniciou-se em terras brasileiras ${ }^{5}$. Outra hipótese possível para compreender o uso do termo "petróleo" é a associação com combustível e, portanto, com algo explosivo. Essa aplicação permite considerar que as notícias publicadas em $A$ Reforma pretendiam "incendiar" o debate político do Brasil dos oitocentos.

A ilustração confeccionada por Henrique Fleiuss possui detalhes relevantes em sua elaboração, os quais configuram diferenças se comparados com os desenhos analisados acima (Figuras 1 e 2). A primeira remete à questão já abordada no começo do artigo sobre os posicionamentos dos periódicos. O caráter cômico do desenho da Semana Illustrada apresenta, igualmente, uma posição contrária aos ideais republicanos e aqueles defendidos pelos liberais radicais. Em segundo lugar, a imagem de Fleiuss se aproxima mais de uma caricatura, ou seja, as expressões das alegorias foram deturpadas, e seus traços físicos foram acentuados, resultando em algo exagerado (BELLUZZO, 1992). A ilustração com as duas comadres pode ser averiguada como uma caricatura. No entanto, ela não trata de uma pessoa. Ambas são caricaturas de duas alegorias femininas que representam os jornais $A$ República e $A$ Reforma. Ainda, podem ser 
vistas como uma sátira aos ideais que eram defendidos pelos simpatizantes das folhas, o que foi tomado de maneira mais acentuada no caso do jornal $A$ República. A legenda da ilustração narra a ação que se passava: "As duas comadres República e Reforma preparando as suas armas para um conflito, uma guerra, um bombardeamento, e Deus sabe o que mais, dando graças à Providência por ter fornecido este pano para mangas que enche diariamente algumas colunas".

A legenda deixa clara a posição crítica adotada pela Semana em relação aos dois órgãos políticos e aos ideários que defendiam. A palavra "comadre" certamente foi empregada como sinônimo de "alcoviteira", já que, no ponto de vista do periódico, os assuntos abordados pelos jornais eram boatos, notícias aumentadas ou falsas, como aquelas que anunciavam as descobertas de petróleo. A mesma atitude foi verificada num artigo chamado "Notícias falsas" no qual o articulista da Semana criticava alguns jornais da Corte por publicarem noticiários falsos. Tanto $A$ República como $A$ Reforma não escaparam. Sobre a primeira, era pedido que fosse mais exata na publicação das novidades sobre os abalroamentos das barcas, pois noticiavam "ferimentos graves de indivíduos em brigas individuais, quando estas feridas não passam de um arranhão" (Semana Illustrada, 05/11/1871). O autor entendia o procedimento da redação do jornal, visto que "assim é a mocidade", o que denotava uma crítica aos redatores considerados por ele jovens demais para estar à frente de um órgão político. A parte referente ao jornal $A$ República encerra aconselhando os redatores a acalmarem o espirito. Já ao se referir a $A$ Reforma, destaca que os boatos acabaram "[...] porque já o título os declarou falsos, e ainda mais porque $A$ Reforma reconheceu que ela toda estava composta de boatos".

A ilustração e o artigo veiculados na Semana Illustrada podem ser considerados como antirrepublicanos ou ainda contrários às ideias novas, se forem considerados os manifestos do Centro Liberal, que fundou o jornal A Reforma. Por outro lado, a posição verificada nesse desenho igualmente tinha por objetivo criticar outra ideia nova, aquela dos republicanos. É possível que Henrique Fleiuss considerasse todos esses elementos como perigosos às bases que sustentavam o Império e, como amigo do Imperador, tentou frear as suas campanhas com a veiculação de 
Os símbolos da República nas páginas do humor: Política e imprensa...

imagens contrárias a eles. Para amparar essa defesa, aproveitouse da alegoria feminina da República, embora sua utilização fosse invertida, ou seja, ao invés de abordar os ideais republicanos (e liberais) de uma forma positiva, as alegorias foram confeccionadas com o objetivo de denegri-los.

Duas colegas

Outra ilustração, desta vez veiculada em O Mosquito, apresentava novamente os dois jornais como alegorias femininas (Figura 4).

Figura 4: Duas colegas

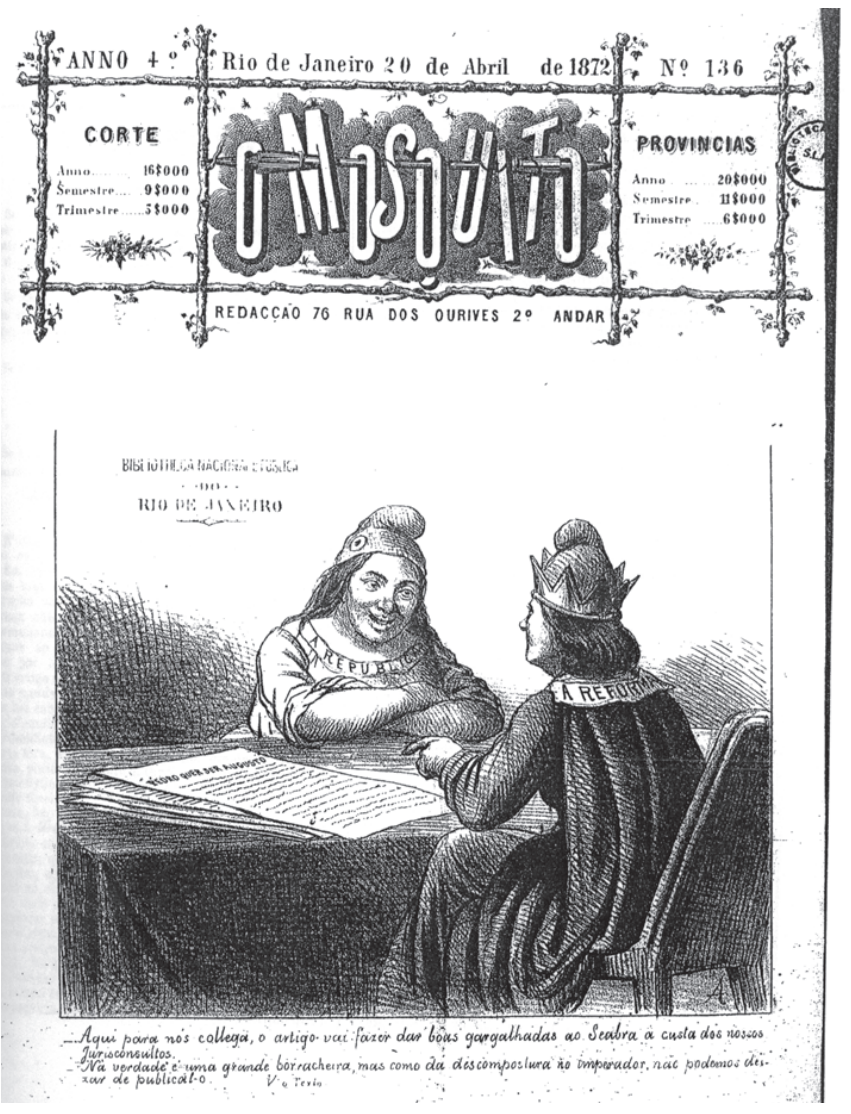

Fonte: O Mosquito, Rio de Janeiro, n. 136, capa, 20 abr. 1872. Acervo: AEL-UNICAMP 
Essa é de autoria de Angelo Agostini, conforme se verifica na letra A colocada no canto inferior direito da imagem. No desenho, $A$ República e $A$ Reforma conversam sobre a veiculação de um artigo nos seus jornais. Ao contrário das alegorias da Semana produzidas por Henrique Fleiuss, analisadas acima, essas não foram concebidas numa visão caricatural exacerbada; é possível considerar que elas foram apresentadas em tom simpático. Contudo, é visualizado um tom zombeteiro ao verificar o rosto arredondado da alegoria da República que não lembra as versões clássicas das alegorias, com um rosto mais afinado e corpo esguio. As expressões, no entanto, se comparadas com aquelas das alegorias de Fleiuss, não foram carregadas. O sorriso da alegoria da República não possui aquele aspecto trocista da imagem anterior, e apesar da alegoria do jornal A Reforma estar de costas, percebe-se que seu rosto, apresentado de perfil, não foi exagerado.

O barrete frígio de $A$ República é o mesmo que aparece em outras ilustrações, mas aquele usado pelo $A$ Reforma está envolvido por uma coroa, o que caracteriza a posição do partido: apesar das ideias reformistas defendidas por seus membros, ainda se mantém vinculado à Monarquia. Por outro lado, é possível considerar que o barrete assim apresentado fosse um recurso do artista ao se referir a certos colaboradores da folha liberal que mantinham uma posição mais radical e, portanto, associada aos republicanos. A legenda explica o tom do diálogo das duas alegorias:

- Aqui para nós colega, o artigo vai fazer dar boas gargalhadas ao Seabra a custa dos nossos jurisconsultos.

- Na verdade é grande borracheira mas como dá descompostura no Imperador, não podemos deixar de publicá-lo. (vide o texto)

O assunto abordado na ilustração foi desenvolvido num artigo publicado na página dois do mesmo número do periódico na sessão intitulada "Chronica", que abordava temas variados sempre com esse mesmo título. Esse emprego foi corriqueiro nos periódicos ilustrados, que como eram semanais, apresentavam um resumo das notícias que recebiam destaque durante a semana, ou então se 
Os símbolos da República nas páginas do humor: Política e imprensa...

destinavam a dissertar sobre um tema específico, como o deste número. Segundo a crônica de O Mosquito, o artigo de autoria de Augusto Teixeira de Freitas, foi publicado tanto em $A$ Reforma como em $A$ República, e intitula-se "Pedro quer ser Augusto" (O Mosquito, 20/04/1872).

O colaborador do periódico afirmava que o texto ocasionoulhe "agradáveis risotas" devido ao artigo ser "[...] talvez bom, talvez mau, mas mais pandego é que não podia estar". Em sequência, direciona sua crítica aos dois jornais que, ao publicarem esse artigo, esqueceram "por um momento as suas ideias particulares em política", o que foi visto como uma atitude mercadológica: "Bem haja eles que não fazem da imprensa uma praça do mercado".

O artigo "Pedro quer ser Augusto" foi publicado no jornal $A$ Reforma no dia 14 de abril de 1872 na seção "Parte não editorial", e em $A$ República no dia seguinte, 15 de abril de 1872, na seção "Ineditoriaes". Essas seções assim denominadas retiravam dos redatores dos jornais a responsabilidade por tal artigo. O autor apresenta uma crítica ao projeto de Código Civil encaminhado ao Imperador Dom Pedro II pelo jurisconsulto português Luis de Seabra, em 1871. A proposta do código, contudo, não foi aceita pelo Império. O teor do artigo fazia uma crítica à ausência de referências à religião e à Igreja Católica; afirmava, por exemplo, que o Código Civil português, do qual Seabra foi um dos autores, "[...] nega em seu artigo primeiro as obrigações do homem para com Deus” (A Reforma, 14/04/1872). O esboço de código civil para o Brasil igualmente previa essas considerações. Dessa forma, afirma que o Imperador Dom Pedro II queria ser como o Imperador Augusto de Roma, que perseguia os cristãos ${ }^{6}$.

Baseando-se no artigo publicado em $A$ Reforma e na ilustração de O Mosquito, é possível traçar algumas observações em relação ao debate político e as atitudes dos partidos Liberal e Republicano, assim como o posicionamento de Angelo Agostini. Inicialmente, o artigo, apesar de ser publicado numa seção que salvaguardava os redatores do jornal liberal, apresentava uma crítica ao império. Dessa forma, justifica o tom jocoso do texto do periódico ilustrado, que considerava que ambos os jornais haviam esquecido seus propósitos políticos e teriam recebido um pagamento para a veiculação do texto. A última citação revela uma ironia ao empregar a palavra 
"não", ou seja, os dois jornais transformavam sim a imprensa em "praça de mercado", publicando qualquer texto desde que fosse uma crítica ao Império.

Em relação a Agostini, é necessário considerar a sua posição contrária à associação entre o governo monárquico e a religião, para entender a elaboração da crítica presente na ilustração. Quando as discussões em torno da chamada Questão Religiosa tomaram maior fôlego (o que ocorreu no mesmo ano da ilustração e um pouco antes de sua veiculação), os periódicos do Império mantiveram uma posição semelhante, contrária à associação do governo com a religião, entre os quais estava O Mosquito (LIMA, 1963, p. $242)^{7}$. Se o projeto do código civil para o Brasil desconsidera essa relação, isso seria importante para o progresso nacional, já que para O Mosquito - e Agostini - a ligação do Império com a Igreja era vista como algo retrógrado. A crítica de Agostini aos jornais liberais e republicanos está associada a esta questão, ou seja, se o artigo de Teixeira de Freitas critica a falta de religião no esboço do código civil para o estado brasileiro, por que dar visibilidade para tal artigo? A resposta está na legenda da ilustração: se o texto for crítico, apesar de ser uma "grande borracheira", se causa "descompostura ao Imperador", ele será publicado, independentemente do assunto abordado. A legenda, dessa forma, aponta a crítica de Agostini aos jornais e à falta de critérios na seleção dos artigos.

Retornando à ilustração de O Mosquito e comparando-a com aquela veiculada na Semana Illustrada, é possível desenvolver alguns comentários. A ilustração concebida por Henrique Fleiuss apresenta uma visão caricata dos jornais $A$ República e $A$ Reforma: as duas alegorias, com traços acentuados, foram identificadas como duas comadres. A visão cômica de Fleiuss nesta ilustração é bastante clara e sua posição em relação aos ideais que nela estavam sendo criticados parece ser desfavorável. Ao empregar palavras como "veneno" e "petróleo" na ilustração e ao se referir, no artigo, às notícias consideradas falsas que eram publicadas nos jornais, Fleiuss faz uma crítica mais geral aos ideários defendidos nas páginas de $A$ República e $A$ Reforma.

Já na ilustração de autoria de Angelo Agostini o tom jocoso foi mais ameno. As alegorias aparecem com suas expressões não carregadas, e nenhum apelido foi a elas apregoado. Como visto acima, a 
Os símbolos da República nas páginas do humor: Política e imprensa...

sátira estava presente, mas era direta ao se referir à veiculação de um artigo específico publicado por ambos os jornais; assim, a crítica não parece ser direcionada aos ideários defendidos pelos órgãos partidários. Isso não significa, no entanto, que $O$ Mosquito não tenha tomado uma posição mais aguerrida em relação aos partidos e seus órgãos oficiais em outros momentos. O periódico adotou uma posição satírica, em especial, ao jornal $A$ República, o que será visto a partir da próxima ilustração sobre Quintino Bocaiúva, um dos principais propagandistas da República.

\section{Quintino Bocaiúva: de Esbodegado à Jornalista valoroso}

Além das alegorias femininas da República, os adeptos republicanos também foram aproveitados pelos periódicos para a elaboração de críticas e sátiras ao ideário republicano. Entre outros, se destacaram na produção dos desenhos: Lafayette Rodrigues Pereira, Joaquim Saldanha Marinho e Quintino Bocaiúva. Em certos momentos, os símbolos da República eram concebidos interagindo com seus propagadores. Quintino Bocaiúva foi o republicano mais aproveitado pelos caricaturistas da imprensa ilustrada do Rio de Janeiro na composição dos desenhos. Ele surgia, quase sempre, associado ao jornal $A$ República e à sua atuação como seu redator, a qual foi mantida por ele até o fim do jornal, em 1874. Os anos de circulação do jornal republicano foram acompanhados por Angelo Agostini e o seu encerramento não lhe passou despercebido. O caricaturista dedicou uma de suas ilustrações em $O$ Mosquito a notícia sobre o último número d'A República. Publicado em 04 de março de 1874, o desenho apresenta um curto diálogo entre a Alegoria Feminina da República e Quintino Bocaiúva (Figura 5). 


\section{Figura 5: Moça bonita}

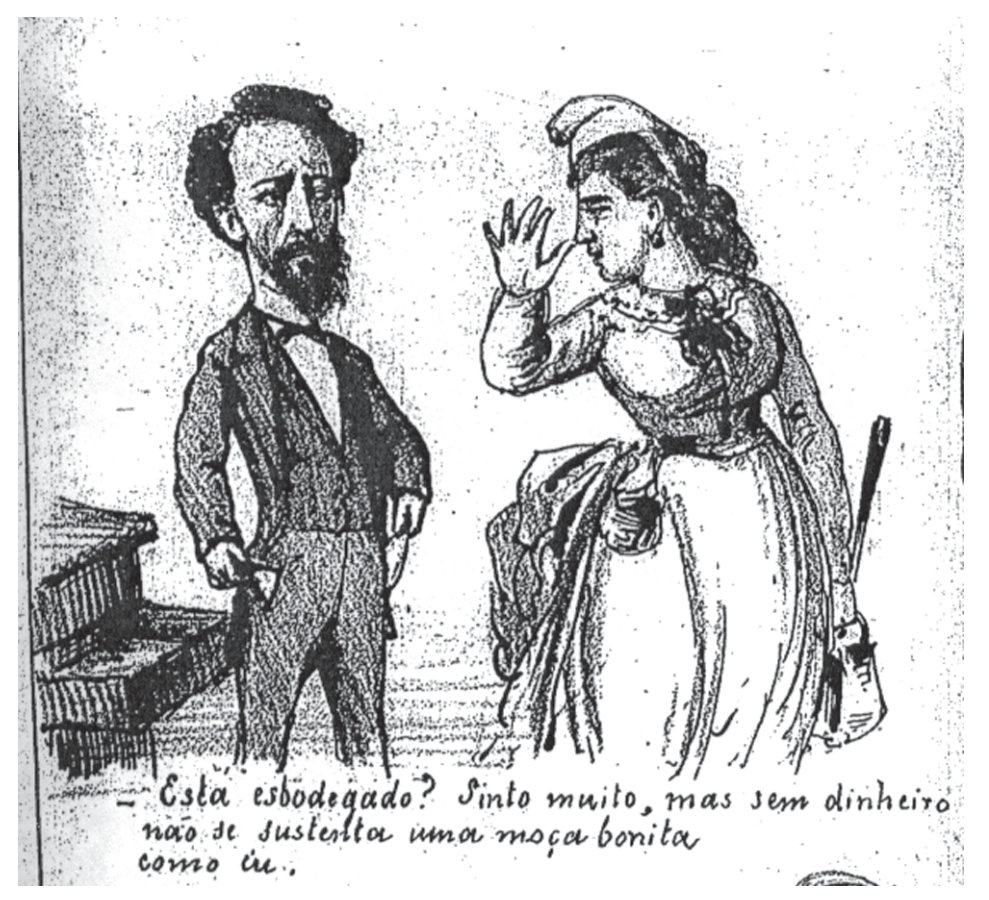

Fonte: O Mosquito, Rio de Janeiro, n. 234, p. 4, 07 mar. 1874. Acervo: AELUNICAMP

O periódico anunciava aos leitores o fim da folha republicana num tom que pode ser visto como amigável, porém satírico; o desenho apresenta Quintino Bocaiúva mostrando os fundos dos bolsos e a gaveta vazia para a alegoria feminina da República; esta, por sua vez, faz-lhe um gesto de desdém e pergunta: "Está esbodegado? Sinto muito, mas sem dinheiro não se sustenta uma moça bonita como eu". No ponto de vista cômico do jornal só se mantinha a causa republicana (e uma moça bonita) com dinheiro.

O tom crítico dirigido a Quintino Bocaiúva, conforme se evidencia nessa ilustração, não se manteve o tempo todo. Num dos últimos números de $O$ Mosquito ele foi homenageado na primeira página (Figura 6). 


\section{Figura 6: Quintino Bocaiúva}

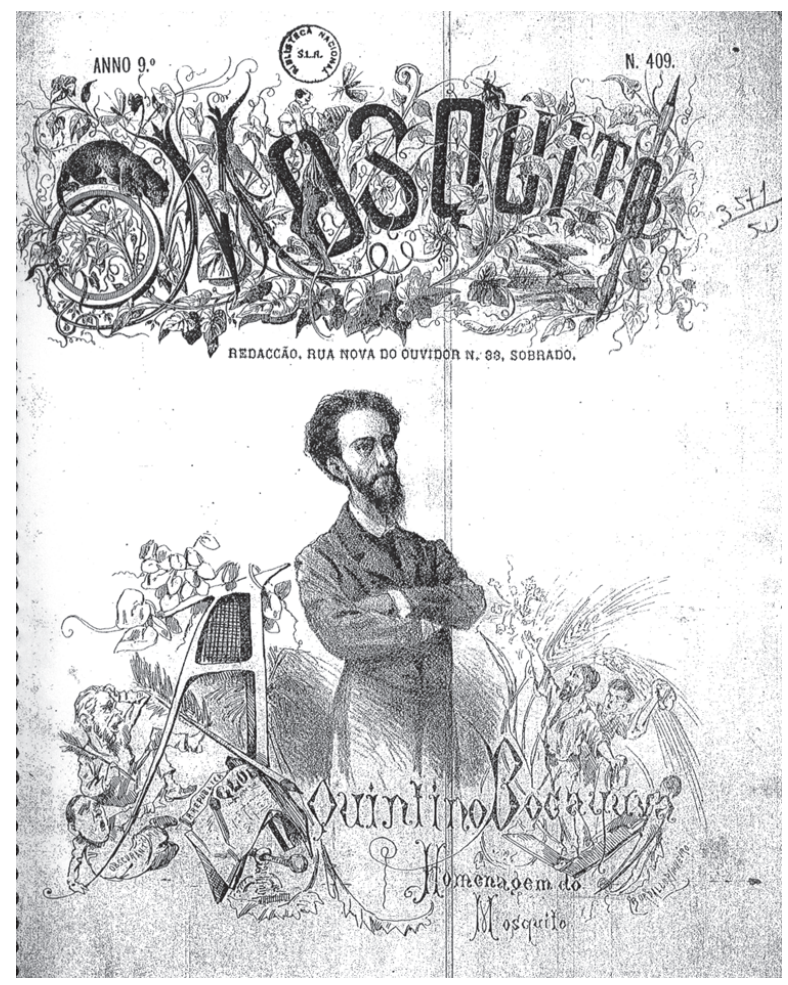

Fonte: O Mosquito, Rio de Janeiro, n. 409, capa, 07 abr. 1877. Acervo: AEL-UNICAMP

O retrato de Quintino Bocaiúva foi confeccionado pelo caricaturista português Rafael Bordallo Pinheiro, que veio para o Rio de Janeiro substituir Agostini na parte ilustrada do periódico, a partir de 1875 (LIMA, 1963, p. 886). Bordallo Pinheiro já era consagrado em Portugal com suas produções artísticas nos jornais de caricatura como O calcanhar d'Achuilles, A Berlinda e O Binóculo (PINTO, 1915, p. XXV). Permaneceu no Brasil até 1879, publicando caricaturas; após o fim de O Mosquito, trabalhou nos periódicos Psit!!! (1877) e O Besouro (1878). Ao retornar para Portugal seguiu publicando seus desenhos em $O$ Antonio Maria e no Álbum das Glórias.

O retrato de Quintino Bocaiúva é característico do lápis de Bordallo, que modificou a parte gráfica do periódico, como se depreende dos cabeçalhos rebuscados veiculados a partir de $1876^{8}$. Não é apenas um desenho do jornalista: ele foi envolvido com uma série de elementos que lembravam a sua vida profissional. Foram retomados os seus trabalhos à frente do jornal O Globo, que estava em circulação 
naquele momento, e em $A$ República, ambos referendados à esquerda. Logo abaixo dos nomes dos jornais é possível identificar uma prensa tipográfica.

Os dois homens colocados também à sua esquerda representam adversários do jornalista, o que se depreende dos olhares assustados dos dois que contrastam com a atitude altiva do homenageado. Eles poderiam ser outros jornalistas, visto que um deles está com uma pena na mão enquanto o outro, que foi identificado com a palavra "obscurantismo", parece ser um padre, o que denota a ação contrária às atividades clericais produzidas por Quintino, posição compartilhada pelo periódico que também era anticlerical. Já os homens que foram colocados à sua direita são difíceis de serem identificados. Eles são homens do povo, o que pode ser visto nas roupas simples empregadas pelo caricaturista para vesti-los; ambos estão saudando o jornalista como se depreende das atitudes de seus braços. Pode, ainda, ser uma referência aos leitores dos jornais que contaram com a participação de Quintino. Por outro lado, se são homens do povo devem ser também operários, e nesse sentido a referência pode ser outra.

Quintino Bocaiúva era maçom, e operário é um termo caro às lojas maçônicas, sendo empregado por eles para se referirem uns aos outros. Reforçando essa hipótese, é possível ver logo abaixo desses homens, um pouco entrelaçados entre os demais itens do desenho, dois símbolos da maçonaria: o esquadro e o compasso. $\mathrm{O}$ homem que está na frente está com o seu pé esquerdo no centro do esquadro, enquanto o compasso está ao lado. Daí a assimilação singela e discreta feita na homenagem, colocando referências que lembravam a índole do representado: sua atividade profissional no jornalismo republicano e sua orientação maçônica. Ainda há no desenho ramos de trigos que aludiam à prosperidade que era desejada ao homenageado por Bordallo Pinheiro, que assinava a produção no canto inferior direito.

Ầ ilustração, um pequeno texto na página seguinte do periódico foi dedicado, explicando o porquê da homenagem. Conforme o periódico, alguns amigos e admiradores de Quintino Bocaiúva decidiram abrir uma subscrição para oferecer-lhe um brinde, "[...] como prova de consideração ao seu talento, e como tributo de gratidão pelos serviços que tem prestado ao país". O brinde não era revelado. 
Os símbolos da República nas páginas do humor: Política e imprensa...

Contudo, não se tratava de uma sátira, visto que o teor do texto priorizava as bem-aventuranças do jornalista: " $E$ um jornalista valoroso, de olhar seguro e profundo, de consciência reta e sã, lutando sem descanso pelo bem do país, pelo progresso e pela civilização".

O jornal que outrora publicou sátiras contundentes às atitudes de Quintino Bocaiúva - como averiguado na ilustração que tratou do encerramento d'A República, a qual é somente um exemplo entre vários outros desenhos que o satirizavam - agora parecia se redimir frente as suas tomadas de posições do passado. No entanto, aquelas saíram do lápis de Angelo Agostini, e neste instante o jornal apresentava um perfil e caricaturista novos. Bocaiúva aparecia, finalmente, na página do periódico sem ser "picado" pela verve humorística de O Mosquito.

\section{Considerações Finais}

As ilustrações analisadas no artigo fazem parte de um conjunto maior de imagens sobre o debate político e o ideário republicano, que foram veiculadas nos jornais que circularam nos anos 1870 no Rio de Janeiro. Assim, é possível verificar que a campanha republicana, embora tímida, foi desenvolvida na Corte do Império do Brasil desde aquela década. O ideário republicano, sua campanha e seus defensores surgiram nas páginas dos periódicos de forma crítica, satirizados e em certos momentos num tom amistoso, como na homenagem a Quintino Bocaiúva. É pertinente considerar que os caricaturistas, mesmo adotando posições distintas, confeccionaram seus desenhos a partir de um ponto de vista particular sobre a República e seu ideário. Dessa forma, passavam aos seus leitores a sua visão de mundo. Descreviam, como enfatiza Roger Chartier (2002, p. 19), "[...] a sociedade tal como pensam que ela é, ou como gostariam que fosse”. Em outras palavras, expressavam em seus desenhos suas opiniões sobre o que entendiam em relação à política do tempo e, nesse caso, as percepções em relação ao debate político e ao ideário republicano.

$\mathrm{Na}$ elaboração de suas produções artísticas, os desenhistas aproveitaram os símbolos usados pelos republicanos na difusão dos seus ideais. Numa clara releitura dos elementos simbólicos revolucionários 
e republicanos franceses - e mesmo adotando um tom nem sempre simpático aos republicanos - a campanha por uma mudança política no Brasil surgiu, indiretamente, nas páginas dos periódicos. A partir da década de 1880, as discussões políticas começaram a tomar as ruas do Rio de Janeiro (MELLO, 2007, p. 14) e as ilustrações relacionadas a República surgiram com mais afinco nos jornais ilustrados.

Nesse sentido, é possível concordar em parte com Renato Lessa quando afirma em seu ensaio que é um engano considerar o golpe de 15 de novembro de 1889 como a:

[...] materialização de um projeto de utopia, lentamente amadurecido por duas décadas de ação republicana. Talvez seja mais prudente supor que a relevância da propaganda republicana se deve, apenas, ao fato de que se proclamou uma República, que lhe reivindicou como memória (LESSA, 1988, p. 38).

A Proclamação foi uma atitude militar e a participação civil foi quase nula, o que mudaria somente no período pós-proclamação, quando políticos republicanos, oriundos da propaganda, tiveram um papel importante na organização do novo regime (CASTRO, 1995 , p. 176). O que não é correto é considerar que a atividade da propaganda republicana não existiu nos anos anteriores.

Como visto nas ilustrações dos periódicos ilustrados analisados neste artigo, a campanha foi desenvolvida desde 1870, embora seu empenho não alcançasse os objetivos pretendidos de forma imediata. A mudança de regime somente foi concretizada com a entrada dos militares em cena. Contudo, não se deve esquecer da campanha desenvolvida antes da Proclamação. Ainda, as atividades republicanas desempenhadas no Brasil Imperial foram importantes no cenário da política do século XIX. A importância dessas atividades deve-se à atenção a elas dirigida pelos caricaturistas que as levaram para suas páginas de humor e de sátira. Por outro lado, considerar a atividade republicana como mero artifício de reivindicação de memória é desprezar toda a atividade exercida pelo Partido Republicano e seus adeptos, fosse através da imprensa republicana, fosse nos clubes. Tais ações não ficaram restritas somente ao Rio de Janeiro, mas 
Os símbolos da República nas páginas do humor: Política e imprensa...

se estenderam para outras províncias ${ }^{9}$. A campanha republicana não é apenas um artifício, mas parte importante da memória da República no Brasil.

\section{REPUBLIC SYMBOLS IN HUMOR PAGES: POLITICS AND ILLUS- TRATED PRESS IN RIO DE JANEIRO IN THE 1870'S.}

Abstract: Illustrated periodicals in Rio de Janeiro gained prominence after the middle of the XIXth. Part of their success was due to their peculiar characteristics, in other words, in addition to make announcements, their purpose was also to make the reader laugh through humorous drawings. On the other hand, foreigner artists have also contributed to develop and reinforce this type of press activities in Imperial Brazil. In all the subjects approached on its pages, the focus on politics stands out. Among these illustrations republican symbols emerged to address republican ideas transmitted by their supporters. The purpose of this article is to analyse relations among these symbols, republican political discussions and humor in the periodicals. In this moment, the focus is on one of the republican symbols - female allegories used by cartoonists in their illustrations.

Keywords: Illustrated press. Republican symbology. Rio de Janeiro. XIX Century.

\section{Notas}

${ }^{1} \mathrm{O}$ emprego de alegorias inspiradas na Antiguidade Clássica, contudo, já era difundido nas artes da Europa antes da Revolução Francesa, como salienta Jean Starobinski (1988, p. 17): “[...] precede à revolução; o gosto neoclássico se afirmou e se difundiu em seguida, a partir de 1750. As formas que a Revolução porá a seu serviço já estão inventadas antes de 1789".

${ }^{2}$ A grafia das citações dos periódicos foi atualizada.

${ }^{3}$ Angelo Agostini, por exemplo, depois de sua passagem por São Paulo, colaborou em alguns periódicos da Corte, e em 1876, com a fundação da Revista Illustrada se tornou um dos caricaturistas mais conhecidos do século XIX.

${ }^{4}$ A simbologia da união representada pelas fasces foi uma das inspirações que levou ao surgimento do Fascismo na Itália. Um histórico do fascismo que aborda a reutilização da simbologia pode ser consultado em Paxton (2007).

${ }^{5}$ Sobre a história do petróleo, ver: $<$ http://www2.petrobras.com.br/EspacoConhecer/HistoriaPetroleo >. Acesso em: 21 jan. 2010.

${ }^{6}$ Teixeira de Freitas foi autor da Consolidação das leis civis e tinha conhecimento de outros exemplos de códigos civis e projetos, como a produção do jurista inglês 


\section{Aristeu Machado Lopes}

Jeremy Bentham (GRINBERG, 2001, p. 26), e certamente conhecia com propriedade a proposta apresentada por Luis de Seabra. Leila Grinberg (2001, p. 32) destaca que "[...] por mais que a importância da codificação civil fosse sempre enfatizada como um providência fundamental para a finalização do processo de independência do Brasil e para a própria modernização do estado, àquele momento (anos 1870) já se sabia que o Código Civil não iria solucionar absolutamente todos os problemas do direito". Colonialismo, catolicismo e escravidão constituíam alguns desses problemas. No entanto, pelo teor do artigo publicado por Teixeira Freitas, parece que o catolicismo não significava, necessariamente, um problema. ${ }^{7}$ Sobre a Questão Religiosa, ver: (VIEIRA, 1980). Já em relação à crítica dirigida à religião nos periódicos ilustrados da Corte, ver: (LIMA, 1963, p. 238-247), e uma análise mais precisa sobre as ilustrações de Angelo Agostini sobre a questão religiosa, (BALABAN, 2009, cap. 3, p. 229-335).

${ }^{8}$ A primeira página do número 330 publicado no dia 06/01/1876 dava início ao traço característico dos desenhos de Rafael Bordallo Pinheiro. Nesta, O Mosquito é apresentado num clima tropical, envolvido por plantas e animais nativos do Brasil, uma mulata e outras duas mulheres. No cabeçalho, também estava o caricaturista vestido de índio e montado no mosquito. Uma versão resumida deste cabeçalho acompanha a ilustração com o retrato de Quintino Bocaiúva analisado neste artigo.

${ }^{9}$ Como exemplo, citam-se as atividades dos republicanos rio-grandenses, encabeçados por Júlio de Castilhos, a frente do jornal oficial do partido, A Federação. Sobre Júlio de Castilhos e a campanha republicana no Rio Grande do Sul, ver: (FRANCO, 1996).

\section{Fontes:}

Arquivo Edgard Leuenroth

Universidade Estadual de Campinas (AEL-UNICAMP):

Semana Illustrada (1869-1876)

O Mosquito (1869-1877)

A Vida Fluminense (1868-1875)

Hemeroteca Digital Brasileira (www.hemerotecadigital.bn.br)

Fundação Biblioteca Nacional:

A Reforma (1872)

A Republica (1872) 
Os símbolos da República nas páginas do humor: Política e imprensa...

\section{Referências:}

AGULHON, Maurice. Marianne au combat. L'imagerie et la symbolique républicaines de 1789 à 1880. Paris: Flammarion, 1979.

ALONSO, Angela. Ideias em movimento. A geração de 1870 na crise do Brasil-Império. São Paulo: Paz e Terra, 2002.

BALABAN, Marcelo. Poeta do Lápis. Sátira e política na trajetória de Angelo Agostini no Brasil Imperial (1864-1888). São Paulo: Editora da UNICAMP, 2009.

BELLUZZO, Ana Maria de Moraes. Voltolino e as raizes do modernismo. São Paulo: Marco Zero, 1992.

BOEHRER, George. Da Monarquia a República. História do Partido Republicano do Brasil (1870-1889). Tradução Berenice Xavier. Belo Horizonte: Itatiaia, 2000.

CARVALHO, José Murilo de. A Construção da ordem: a elite política imperial. Teatro de sombras: a política imperial. $2^{\mathrm{a}}$ Ed. Rio de Janeiro: Civilização Brasileira, 2006.

- A formação das almas. O imaginário da República no Brasil. São Paulo: Companhia das letras, 1990.

- As conferências radicais no Rio de Janeiro: novo espaço de debate. In:

Nação e cidadania no Império: novos horizontes. Rio de Janeiro: Civilização Brasileira, 2007, p. 17-41.

CASTRO, Celso. Os militares e a República. Um estudo sobre cultura e ação política. Rio de Janeiro: Jorge Zahar Editor, 1995.

CHARTIER, Roger. À Beira da Falésia a História entre certezas e Inquietude. Tradução Patrícia Chittoni Ramos. Porto Alegre: Ed. da Universidade/UFRGS, 2002.

COSTA, Emilia Viotti da. Da Monarquia à República. Momentos decisivos. $8^{a}$ Ed. São Paulo: Editora da UNESP, 2007.

FERREIRA, Athos Damasceno. Imprensa Caricata do Rio Grande do Sul no Século XIX. Porto Alegre: Globo, 1964.

FONSECA, Joaquim da. Caricatura. A imagem gráfica do bumor. Porto Algre: Artes e Ofícios, 1999.

FRANCO, Sérgio da Costa. Júlio de Castilhos e sua época. $3^{\mathrm{a}}$ Ed. Porto Alegre: UFRGS, 1996.

GRINBERG, Keila. Código civil e cidadania. Rio de Janeiro: Jorge Zahar Editor, 2001.

GUIMARÃES, Lúcia Maria Paschoal. Henrique Fleiuss: vida e obra de um artista prussiano na Corte (1859-1882). ArtCultura, Uberlândia, v. 8, n. 12, jan-jun-2006, p. $85-95$. 


\section{Aristeu Machado Lopes}

HOLANDA, Sérgio Buarque de. História Geral da Civilização brasileira. Vol. 7: Do Império à República. $7^{\text {a }}$ Ed. Rio de Janeiro: Bertrand Brasil, 2005.

HUNT, Lynn. Política, cultura e classe na Revolução Francesa. Tradução: Laura Teixeira Motta. São Paulo: Companhia das Letras, 2007.

LESSA, Renato. A invenção republicana. Campos Sales, as bases e a decadência da Primeira República brasileira. Rio de Janeiro/São Paulo: IUPERJ/Vértice, 1988.

LIMA, Herman. História da caricatura no Brasil. Rio de Janeiro: José Olympio, 1963.

LUCA, Tania Regina de. História dos, nos e por meio dos Periódicos. In: PINSKY, Carla (Org.) Fontes Históricas. São Paulo: Contexto, 2006, p. 111-153.

. Leituras, projetos e (re)vistas do Brasil. (1916-1944). São Paulo: UNESP/ FAPESP, 2011.

MELlO, Maria Tereza Chaves de. A República Consentida. Cultura democrática e científica do final do Império. Rio de Janeiro: FGV/UFRJ, 2007.

PAXTON, Robert. A anatomia do Fascismo. Tradução Patrícia Zimbes e Paula Zimbes. São Paulo: Paz e Terra, 2007.

PINTO, Manoel de Souza. Bordallo e a Caricatura. In: Raphael Bordallo PinheiroO caricaturista. Lisboa: Livraria Ferreira, 1915.

SALGUEIRO, Heliana Angotti. A comédia urbana: de Daumier a Porto Alegre. São Paulo: Fundação Armando Álvares Penteado, 2003.

SALIBA, Elias Thomé. Raízes do Riso. A representação bumorística na bistória brasileira: da Belle Époque aos primeiros tempos do rádio. São Paulo: Companhia das Letras, 2002.

SCHWARCZ, Lilia Moritz. As Barbas do Imperador. Dom Pedro II, um monarca nos trópicos. São Paulo: Companhia das Letras, 1998.

STAROBINSKI, Jean. 1789. Os emblemas da rąãa. Tradução: Maria Lucia Machado. São Paulo: Companhia das letras, 1988.

TORAL, André Amaral de. Imagens em desordem. A iconografia da Guerra do Paraguai (1864-1870). São Paulo: Humanitas/FFLCH/USP, 2001.

VIEIRA, David Gueiros. O protestantismo, a maçonaria e a questão religiosa no Brasil. Brasília: Editora da UnB, 1980.

VOVELLE, Michel. Imagens e imaginário na bistória. Tradução Maria Julia Goldwasser. São Paulo: Ática, 1997.

Recebido em 19/07/2012

Aprovado em: 12/11/2012

Anos 90, Porto Alegre, v. 19, n. 36, p. 221-249, dez. 2012 